\title{
Effect of Social Capital on SMEs Performance: Does Innovation Matter?
}

\author{
Tetteh Francis Kamewor ${ }^{1}$, Jamal Mohammed ${ }^{2}$ and Ebenezer Teye ${ }^{3}$ \\ ${ }^{1}$ Department of Supply Chain and Information System, Kwame Nkrumah University of Science and Technology. \\ Email: kameworfrancis@gmail.com \\ ${ }^{2}$ Department of General Studies, Koforidua Technical University, Koforidua. Email: jamalmohammed@,k.tu.edu.gh \\ ${ }^{3}$ Department of Applied Mathematics, Koforidua Technical University, Koforidua. \\ Email: teye.ebenezer94@gmail.com \\ ${ }^{1}$ Correspondence: kameworfrancis@gmail.com
}

\section{Abstract}

The study investigated how social capital influences firms to generate higher performance through innovation among SMEs in Ghana. The study employed a quantitative approach. The study employed stratified sampling to sample 240 respondents from 240 SMEs in the Eastern Region of Ghana. Primary data was gathered using a questionnaire adapted from previously validated instruments. The data gathered was analyzed using Partial Least Square (PLS) of the Structural Equation Model (SEM). The findings proved internal and external factors of the SMEs were found to be strengthened through innovation initiatives of the SMEs. The social capital initiatives of the SMEs positively and significantly enhanced the innovation practices of the SMEs. The result showed internal and external social capital initiatives of the SMEs were positively and significantly associated with the innovation practices of the firms. It concludes that the effect of social capital among SMEs on firm performance is indirectly through their level of innovation practices. The results provide empirical support to the validation of existing theories that a company's utilization of important values offer some level of competitive advantage for superior performance in an industry. We therefore recommended that Owners and Managers of SMEs take advantage of their internal social resources as well as building strategic external capital in the quest to remain competitive and enhance profitability.

Keywords: social capital, innovation, performance structural equation model (SEM)

Citation: Tetteh, F. K., Mohammed, J. and Teye, E. (2021). Effect of Social Capital on SME: Does Innovation Matter? International Journal of Technology and Management Research (IJTMR), Vol. 6 (2): Pp.21 -37 .

Received: February 5, 2021

Accepted: September 1, 2021 


\subsection{Introduction}

Small and Medium scale Enterprises (SMEs) face stiff competition from the global market, hence a prompt response to the adverse implication of competition contributes to a firm's survival during turbulent times (Glenn et al., 2007; Asgary et al., 2020). Globally, the demise of many SMEs could be traced to untimely or inability to withstand the negative implication of competition (Asgary et al., 2020). Yet, there exist a lot more successful SMEs which contribute to the growth of many economies (Bagah et al.,2016). Previous studies (e.g., Chowdhury, 2011; OECD, 2014: Chatterjee et al., 2015: Asgary et al., 2020) indicated that SMEs play a vital role in local, national and global economies through employment and income generation. It is estimated that at least $90 \%$ of firms within developing and developed economies are SMEs and generate between 40-60\% of GDP in these economies (Mbuyisa and Leonard, 2017; Igwe et al., 2018). In Ghana, SMEs thrives the economy (Aryeetey, 2001). As SMEs account for approximately 90 percent of firms and 60 percent of the workforce worldwide (OECD, 2017), it is appropriate to describe this group of firms as the engine and catalyst to economic growth and development (Chichoni, 2011). SMEs enormously contribute to stimulating growth, revenue mobilization, employment creation and poverty alleviation (Sabitu et al.,2019). Ghana's economic landscape like many in Africa that are largely characterized by SMEs accounts for 92 percent of Ghanaian businesses, contributes about $85 \%$ of labour force and provides substantial value to the GDP (Abor \& Quartey, 2010). Again, with such contribution by SMEs to national growth agenda, SMEs are constraint by limited innovative initiatives in the unstable and competitive business environment required to maximize resource utilization to sustain competitive advantage (Akintimehin et al., 2019). Besides the difficulties of SMEs in financing innovation initiatives, social capital deficiency and the limited emphasis on policy provisions are perceived as bottlenecks to the social capital formation (OECD, 2005). As a result of these challenges, most SMEs do not thrive beyond its formative years (Agyapong et al., 2017).

Social Capital is closely linked with the social set up and enhances growth (Dai et al., 2015). It emphasizes capacity to access possessions in the form of personal networks and social connections to detect prospects (Bhagavatula et al., 2010), also, rally financial as well as human capitals (Batjargal, 2003) deemed important for businesses (Stam, et al., 2014). Social capital theory opines the existing common networking or relationship resource among organizational units or individuals is a potential resource for the creation of knowledge and organizational level innovation (Dakhli \& De Clercq, 2004; Parker, Halgin \& Borgatti, 2015). It is therefore evident that higher and efficient firm performance requires both internal and external social wealth (Dai et al., 2015), which could promote knowledge sharing, prevent waste of resources, minimize market imperfections and lower transaction costs (Boschma, 2005). The capacity and skills for the exploitation of social capital are gradually becoming a major and vital resource for gaining a competitive advantage in any industry. Based on this, researchers have developed an enormous curiosity in this subject as it is thought to have economic outcome like performance. Although emphasis is economic, it is a vital predictor of income, and that exploitation of social networks and sharing of knowledge are critical for higher firm performance (Nupus, Setiadi \& Soesanto, 2016). It is a bit vague how social capital enhances general economic outcomes. More so, although its idea of direct linkage between social capital and economic outcomes appeals to researchers and practitioners. It is imperative to identify other constructs through which social capital operates. Thus, it emphasis current enormous dynamic business environment and other related 
variables (see, Erselcan, 2015; Nupus, Setiadi \& Soesanto, 2016; Akintimehin et al., 2019). Nonetheless, literature links social capital, innovation and firm performance have rarely been looked at. Thus, there is rarely any study in the extant marketing and strategic management literature that examines the intricate association. Researchers often assessed social capital as a single construct. Nonetheless, social capital considered multifaceted paradigm, by way of interpersonal, mechanical and reasoning forms of social capital can have varying forms of effect on economic outcomes, and could also react differently to innovative initiatives. This study emphasizes the arguments as a catalyst for innovation in a dynamic marketing environment. The paper is organised into: Section two discussed literature review; the methodology is looked at in section three. Results and discussion are in section four and section five contains conclusions and policy recommendations.

\subsection{Theoretical Review}

Resource-based theory (RBT): according to the RBT, situations could make resources and capabilities which are available as important sources of sustainable competitive advantage (Barney, 1991). Grant (1991), describes resources to include touchable (e.g., equipment) aw well as immaterial which enhance produce supply of services and goods. According to Grant (1996) and Barney (1991), resources can also be recognized as an organization's capabilities, assets, knowledge, competencies and processes which an organization controls to enable them to implement strategies and enhance competitiveness. For (Wernerfelt (1984), a resource is thus recognized as either a strength or a weakness of an organization and the resources among other things include knowledge, skilled personnel, efficient procedures, machinery, reward system, capital, etc. Barney (1991) and Peteraf (1993) have deliberated on the five features of resources which may permit an organization to obtain a truly sustainable competitive advantage. To start with, the resource must be treasured and be that which enhances the organization's efficiency and effectiveness. Secondly, the resource must be uncommon hence the organization can exploit it to the detriment of its competitors when one exercises control over it. Thirdly, the resource must be such that competitors cannot imitate it. fourthly, the resource must be that which cannot be easily be moved that is to say, an attempt to moving it, must cause a damage to it, so that only the organization will have control over it. Finally, the resource should not have a close substitute so that competitors may not have alternative to it. Generally, firms possess both internal and external resources that can be employed in production. Internally, firms can maximize the utilization of human and financial resources in production. Managers and owners of firms require these resources to ensure efficient and sustainable production within an industry. However, resources are limited and scarce and hence require efficient utilization to maximize production. SMEs are confronted with several difficulties in the acquisition and competition for both financial and human resources. Thus, the internal resource capacity of SMEs whether financial or human capital is limited and hence limits their competitiveness and survival within several generations. The situation of resource scarcity is further worsened in a turbulent business environment with prevailing marketing dynamic characteristics. Notwithstanding the financial and technical difficulties of SMEs, competitiveness and firm performance can be enhanced. SMEs in many developing countries like Ghana have limited technical capacity to tap into social networking and many other forms of social capital to increase their resource base and hence improve their competitiveness and performance. Besides tapping into the 
available social capital, firms are required to be more innovative to be highly competitive and high performing in a market dynamic environment.

Social Capital Theory: This study made used of the social capital and adopted its propositions. However, researchers emphasised on the theory of social network as hinged on social capital which is fixed in several levels of relationships. The social capital application pointed to understanding social ties, social interactions, reciprocity, then trust (Pratono, 2018). Past studies on social capital could be grouped into three-way magnitudes (Anandi, 2000; Adler and Kwan, 2002; Aladwani, 2002; Chang et al., 2011). The structural social capital emphasised closure and connection levels amongst the members in the social network. The relational social capital dimension emphasized the social relationship strength of which trust and trustworthiness are the main key factors of relational dimensions.

\subsection{Hypothesis Development}

\subsubsection{Social Capital and Firm Performance}

The social capital theory drives on the relationship among networks to achieve access to resources which can take the form of information benefit not accessible to non-members of the network (Tian et al.,2019; Packer et al.,2020). Entrepreneur's internal network influences financial performance in the process of starting and integrating his business easily and successfully in gathering financial resources to start trading first (Stam et al., 2014; Sforzi and Bianchi, 2020), even outside suppliers may question how new companies' regulation are carried (Stinchcombe, 1965; Akintimehin et al., 2020). There is also a tendency to gain support and recommendations that generate revenue on business introduction platforms that are often notorious for low sales. They are also able to provide links to retailers through their network, thus ensuring a reduction in raw material costs and enhancing value (Fafchamps and Minten, 2002). Innovation can be achieved by raising a large amount of money which is an important tool available through social networks. From the forgoing, both internal and external dimensions of social capital will have positive impact on SMEs performance (Financial and Operational). Hence:

$H_{1}$ : Social Capital (Internal and External) positively impact on financial performance of SMEs performance

$\mathrm{H}_{2}$ : Social Capital (Internal and External) positively impact on operational performance of SMEs performance

\subsection{Innovation as a Moderator in the Relationship between Social Capital and Performance}

Firms are motivated to innovate under difficult marketing conditions that often emanate from dynamic changes and environmental uncertainties. Nonetheless, several studies emphasize that the effect of innovation firm performance is neither direct nor deterministic but require some internal capital stock in the form of social capital (Huang \& Rice, 2009). Many firms in the industry-specific environment are developing enormous interest in utilizing or tapping into social capital to maximize performance. Several studies in the extant literature concur to the positive relationship between social capital and firm performance (e.g., Stam, Arzlanian \& Elfring, 2013; Barroso-Castro, Villegas-Periñan \& Casillas-Bueno, 2015; Akintimehin et al., 2019; Hongyun, Adomako, AppiahTwum \& Akolgo, 2019). These studies emphasize that resources in the form of internal and external capital are now been utilized by firms to gain a competitive advantage in a very uncertain and dynamic business environment. Besides, the existing innovation literature also emphasizes that innovation indirectly exerts some influence on firm 
performance (Farhang, Abkenari \& Fadaee, 2018); and hence provides adequate evidence to indicate that high level of innovation has the potency to strengthen social capital and firm performance. Based on this discussion and the developed empirical relationships, this study hypothesizes the following:

$\mathrm{H}_{3 \mathrm{a}}$ : Innovation moderates the relationship between ISC and firm performance

$\mathrm{H}_{3 \mathrm{~b}}$ : Innovation moderates the relationship between ESC and firm performance

\subsection{Conceptual Framework}

The emphasis of this study is testing the theory of resource-based view with the focus on social capital and innovation as the main dependent resources aimed at promoting a higher level of performance. In a more uncertain and dynamic business environment with an enormous scarcity of resources, organizations including manufacturing firms are beginning to realize the importance of tapping into social capital as a vital resource for attaining competitive advantage in a peculiar industry. Social capital is incongruence in terms of the relationship between the two dimensions of social capital and firm performance (e.g., Stam, Arzlanian \& Elfring, 2013; Barroso-Castro, Villegas-Periñan \& Casillas-Bueno, 2015; Akintimehin et al., 2019; Hongyun, Adomako, AppiahTwum \& Akolgo, 2019). Besides this relationship, the existing literature encompassing the innovation theory emphasizes that innovation indirectly exerts some influence on firm performance (Farhang, Abkenari \& Fadaee, 2018); and hence provides adequate evidence to indicate that innovation has the potency to strengthen the relationship between social capital and firm performance. Notwithstanding, uncertainties of the effect in marketing dynamism, extant literature emphasises the possibilities of firms becoming more innovative in the phase of dynamic marketing environment whereas other studies also report the stressful effect on firm performance. The discussed phenomenon based on the RBV theory and the many studies on the concepts are in Figure 1.

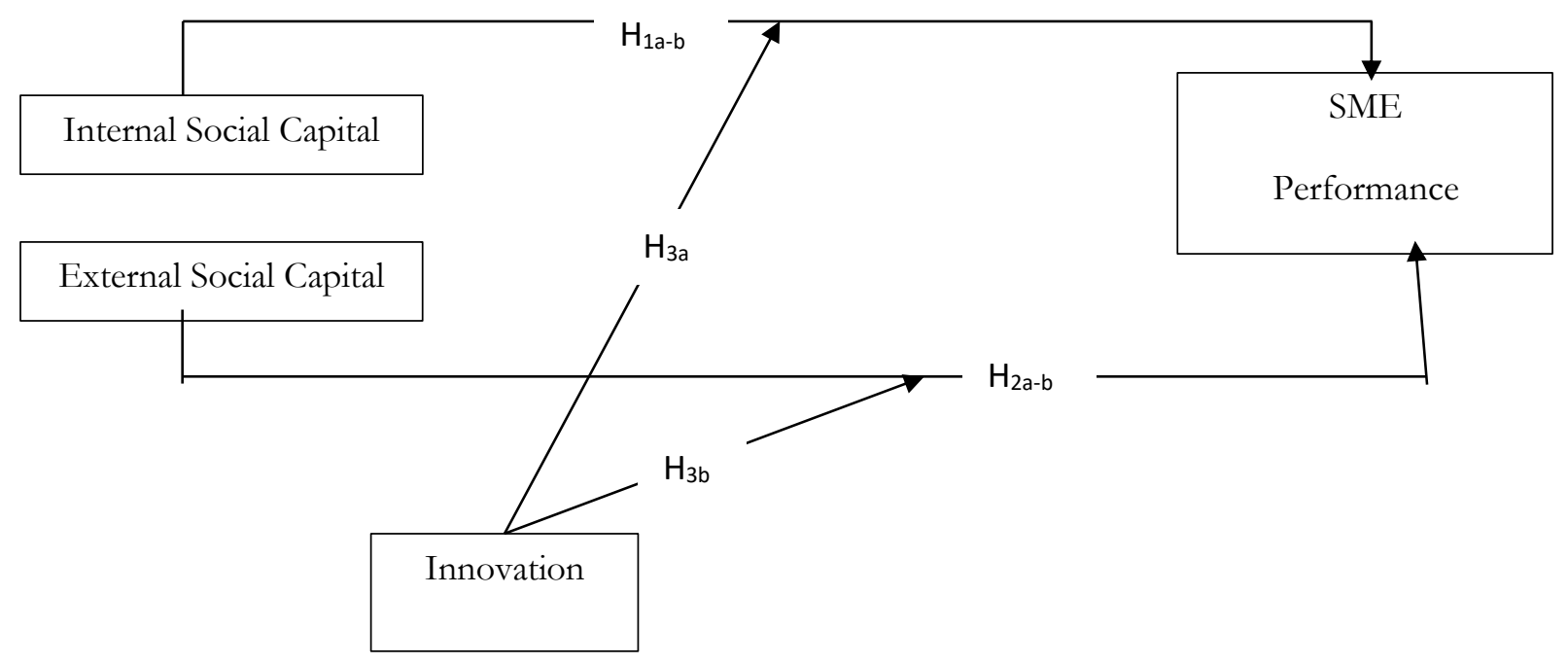

Figure 1: Social capital, innovation and firm performance 


\subsection{Methodology}

\subsection{Study Area}

The study employed a positivist research approach, which enabled the researcher to make use of a questionnaire as the instrument of data collection. Again, the study also adopted an explanatory research design. The developed questionnaire was administered to managers, CEOs, Owners and executives of SMEs through both face-to-face and self-administration methods. In some situations, the researcher had to drop the questionnaires with the participating firms to be picked up later on an agreed date. The questionnaire used in this study comprised four (4) sections. Thus, the first part (Section A) of the questionnaire employed 9-items to measure the background of the surveyed SMEs and background information of the representatives of the SMEs. The information about the firms investigated was industrial type, firm's core activities, years in existence, number of employees, and research and development unit. The structural dimension of social capital was measured using 5-items, the internal dimension was measured using 5-items, and external capital was measured using 5-items. The third part (Section C) of the questionnaire measured dimensions of innovation - product and process. Process innovation was measured using 5-items and product innovation was also measured using 4-items. Part four (Section D) of the questionnaire employed 5-items in the measurement of the performance of SMEs from two main dimensions - Operational and financial. The operational dimension of performance of SMEs was measured using 10-items and the financial dimension of SMEs performance was also measured using 10-items.

These measurement items were largely adopted from several studies in the extant social capital literature (e.g., Coleman, 1990; Krackhardt \& Hanson, 1993; Nahapiet \& Ghoshal, 1998; Seibert et al., 2001). Castro \& Roldán, 2013; Akram et al., 2016; Duffy, Scott, Shaw, Tepper, \& Aquino, 2012; Sanchez-Famoso et al., 2014; Akram et al., 2016; Al-Tabbaa \& Ankrah, 2016). The innovation construct was also measured using both the process and product sub-constructs. Process innovation sub-construct was measured using four main items. Among these items were improvising new methods, development of new processes, the introduction of new service delivery processes and pursuing continuous improvement in the operational process. These items employed in the measurement of process innovation were extracted from several studies in the extant innovation literature (e.g., Vivero, 2002; Langley et al., 2005; Anderson, 2009; Mohd \& Syamsuriana, 2013; Nham et al., 2016). The product innovation sub-construct was also measured using four main items. Among these items were the development of new products, delivering cutting-edge products, promoting new products and constantly experimenting with new products. These items employed in the measurement of product innovation were extracted from several studies in the extant innovation literature (e.g., Alegre, Lapiedra, \& Chiva, 2006; Herrmann, Tomczak, \& Befurt, 2006; Rennings, Andreas, Kathrine, \& Esther, 2006). The performance construct was also measured using two main subconstructs - operational and financial performances. The operational performance sub-construct was measured using ten main items. Among these items were: the extent of flexibility in production, time taking to serve customers, consistency in meeting customer needs, the extent of variety in offered products, resource utilization, time taking to introduce new products, etc. These items employed in the measurement of operational performance were extracted from several studies in the extant operational or non-financial performance literature (e.g., Darroch, 
2005; Bagorogoza and Waal, 2010; Bakar and Ahmad, 2010). The financial performance sub-construct was also measured using ten main items. Among these items were the volume of sales, profit level, market share, return on investment and many others. These items employed in the measurement of financial performance were extracted from several studies in the extant literature (e.g., Garrigos-Simon and Marques, 2004; Marques et al., 2005; Bagorogoza \& Waal, 2010; Tavitiyaman et al., 2012). The study employed a convenience and purposive sampling method to select 240 respondents from 240 SMEs in the Eastern Region of Ghana. Before the data gathering, the research instrument underwent additional pre-testing using 33 Owners of SMEs to ensure content validity. This rigorous approach employed to develop the research instrument compensates for a high level of face and content validity, as well as enhancing the practical relevance and applicability of this study. The main data collection lasted between June to August 2020. Statistical Package for Social Sciences (SPSS) version 23 and SmartPLS 3 software were utilized to conduct descriptive statistics and inferential statistics respectively. The data collected was coded, cleaned, and prepared for analysis. Partial Least Square-Structured Equation Modelling (PLS-SEM) was employed for data analysis. Before the inferential analysis, reliability and data validity were explored using Cronbach Alpha (CA), Average Variance Extracted (AVE), Variance Inflation Factor (VIF) and Common Method Variance (CMV). The Cronbach Alpha values ranges between 0. 850 and 0.943 (see appendix 1). The values are above the recommended threshold of 0.7 (Huang et al, .2017; Nuanally and Berntein, 1994). Composite reliability values were higher than 0.7 while AVE were also greater than .05 threshold (see appendix I). The values indicate the existence of divergent validity among constructs (Hair et a., 2010; Henseler et al., 2016b). The VIF value $(<5)$ indicates that there are no collinearity challenges (Hair et al., 2011).

\subsection{Results and Discussions}

\subsection{None Response Bias and Common Method Variance}

According to Armstrong and Overton (1977), non-response bias can be explored by testing the variation between the early and late responses on a range of variables, thus using late response as a proxy for non-respondents. The researcher grouped the data into two based on the dates of receiving the data, the use of Independent-Samples tTest employed, to test for non-response. The results of the sample distribution of the two groups were statistically indifferent $(\mathrm{P}>0.05)$ across a range of indicators for the constructs and the demographic variables, indicating the non-existence of response bias in the dataset (Armstrong and Overton, 1977). Common Method Variance was also explored as per Harman (1967) recommendation; hence an Exploratory Factor Analysis was conducted and results revealed six (6) factors had Eigenvalues above 1.0, which accounted for $80.7 \%$ of the variance, with the highest factor accounting for $31 \%$ of the explained variance. Since no factor solely explained the majority (50\%) of the covariance, the study concludes that the data has no issues of common method bias. The KMO sampling adequacy of this dimension of the study was 0. 971. The results as presented in Table Appendix 1.

\subsection{Firm Characteristics}

Table 4.1 shows $21.2 \%$ of the firms were in the manufacturing industry, $38.8 \%$ were from the service industry, and $12.9 \%$ were from the agro-based industry. Besides these industries, $27.1 \%$ of the studied firms from other industries. The majority of the surveyed firms were micro (85.4\%) and small (12.9\%) firms with employee sizes of 
2 to 30 employees, and 31 to 99 respectively. Notwithstanding the fact most of the firms have been in existence for an average of $11.30 \pm 6.0$ years (see Table 1), the majority $(80.0 \%)$ have no research and development departments or units. Thus, the innovation practices of the SMEs could further be improved through the development of R\&D units. Forty-two (42) percent of the respondent were owner-managers, 30.1\% were executives and $27.9 \%$ were managers of the surveyed businesses. These respondents have been in their respective current positions for an average of $8.07 \pm 5.56$ years (see Table 1). The gender distribution of these respondent showed that the majority were males whereas $45.8 \%$ were females. Majorly $(71.6 \%)$ were between 30 and 49 years, a category often described as an active and economic potent youthful age group.

Table 1: Firm Characteristics/Respondent Data

\begin{tabular}{llll}
\hline Variables & Category & Frequency $(\mathrm{N}=240)$ & Percent $(\%)$ \\
\hline Firm Specific Factors & Manufacturing & 51 & 21.2 \\
Industry & Service & 93 & 38.8 \\
& Agro-based & 31 & 12.9 \\
& Others & 65 & 27.1 \\
& $2-30$ & 205 & 85.4 \\
Firm Size (Employees) & $31-99$ & 31 & 12.9 \\
& $>99$ & 4 & 1.7 \\
Research \& Dev't & Yes & 48 & 20.0 \\
Respondent Factors & No & 192 & 80.0 \\
Gender & & & \\
& Male & 130 & 54.2 \\
Respondent Age (years) & Female & 110 & 45.8 \\
& $<20$ & 4 & 1.7 \\
& $20-29$ & 40 & 16.7 \\
Position in the Firm & $30-39$ & 99 & 41.2 \\
& $40-49$ & 73 & 30.4 \\
& $50+$ & 24 & 10.0 \\
& Owner-Manager & 92 & 42.0 \\
& Executive & & 30.1 \\
& & 61 & 27.9 \\
\hline Sounager & & &
\end{tabular}

Source: Field Survey (2020)

\subsection{Descriptive and Correlation Analyses}

Table 2 also showed that Operational Performance scored (Mean $=4.165 ; \mathrm{SD}=0.762$ ). Financial Performance scored $($ Mean $=3.98 ; \mathrm{SD}=0.975)$. Innovation scored (Mean = 3.910; $\mathrm{SD}=1.104)$. Internal Social Capital (Mean $=$ 3.740; $\mathrm{SD}=1.069)$ and External Social Capital scored (Mean $=4.093 ; \mathrm{SD}=1.195)$. The descriptive analysis shows 
that Innovation, Internal Social Capital and External Social Capital scored mean above 3.50 indicating that these factors play an important role on the dependent variables (Operational and Financial Performance). The result showed that all two (2) dimensions of social capital practices correlated positively with innovation, internal social capital practices of the firms relatively yielded the highest influence on the innovation of the SMEs. These findings are consistent with the extant literature that emphasizes that innovation is a social process rooted in the environment of the local socio-institution that eventually precipitates greater social ties which further stimulate a higher level of innovation in a competitive environment (Crescenzi, Gagliardi \& Percoco, 2013). The study of Faccina, Genarib and Mackeca (2017) asserted some types of innovation are stimulated indirectly through social capital within a competitive business environment. The study of Dakhli and De Clercq (2004) had in earlier years provided partial support for the positive effect of trust and associational activity on innovation. The internal and external social capital of organizational leadership is also reported to positively influence innovation performance (Chen, Zheng, Yang \& Bai, 2016).

Table 2: Descriptive Statistics and Correlation Analysis

\begin{tabular}{llllllll}
\hline Variables & Mean & StD & $\mathbf{1}$ & $\mathbf{2}$ & $\mathbf{4}$ & $\mathbf{5}$ & $\mathbf{6}$ \\
\hline 1. Operational Performance & 4.165 & 0.762 & 1 & & & & \\
2. Financial Performance & 3.980 & 0.975 & $.703^{* *}$ & 1 & & & \\
3. Innovation & 3.910 & 1.104 & $.499^{* *}$ & $.540^{* *}$ & 1 & & \\
4. Internal Social Capital & 3.740 & 1.069 & $.796^{* *}$ & $.611^{* *}$ & $.511^{* *}$ & 1 & \\
5. External Social Capital & 4.093 & 1.195 & $.627^{* *}$ & $.691^{* *}$ & $.460^{* *}$ & $.637^{* *}$ & 1 \\
\hline
\end{tabular}

3.4 Structural Equation Modelling (SEM)

For measurement model validity and reliability, Confirmatory Factor Analysis was conducted using Smart PLS version 3. The process employed the maximum likelihood estimation method for testing the validity and reliability of the constructs. The model measurement evaluation was conducted, as a pre requisite for the structural model analysis. The model measurement evaluation comprised reliability and validity using Cronbach Alpha (CA), Composite Reliability (CR) and Average Variance Extracted (AVE). The result in Appendix 1 shows that all the constructs had good scale reliability (ie. Cronbach Alpha and Composite reliability) were high than 0.7 (Fornell and Larcker, 1981; Henseler et al., 2015), hence all the constructs had acceptable internal consistency and reliability. Additionally, AVE which was also used to assess convergent validity of the constructs were found above the 0.5 threshold. We further used VIF to examine the issue of multicollinearity. The collinearity statistics for both inner and outer (VIFs) meet the $<3$ threshold as recommended by Ringle et al., (2015). We also employed the FornellLarker criterion and HTMT ratio to assess discriminant validity of the model. The result provide evidence that our model has no issue of discriminant validity, as the square root of the AVEs was higher than expected within correlation mid the variables in the model. The test was further explored using the HTMT ratio, the HTMT threshold $(<0.90)$ was met which also confirms discriminant validity of the research model. Once the measurement model evaluation meets all the reliability and validity thresholds, the next phase of the analysis is the structural model assessment and hypothesis testing via the variances of dependent variables in addition to the model's predictive relevance using stone-Geisser's $\mathrm{Q}^{2}$, path coefficients and significance levels ( $\mathrm{t}$-values). The hypothesis and construct relationship were tested using the standardized path coefficients. The path's significance level was calculated using the bootstrap resampling procedure (Henseler et al.,2009), with 500 iterations of resampling (Chin, 1998). The results as presented in Table 3 below show that the model accounts for 56\% of variations in innovation, $52 \%$ towards financial performance and $67 \%$ toward operational performance. The results presented below show that both internal and external capital dimensions of social capital were found to have a statistically significant effect on SMEs performance (Operational and Financial Performance), all with $\mathrm{p}<$ 0.05 , thus confirming hypotheses $\mathrm{H}_{1 \mathrm{a}-\mathrm{b}}$ and $\mathrm{H}_{2} \cdot \mathrm{a}-\mathrm{b}$. In all, all four (4) direct hypotheses were supported. Again, this 
study envisaged that factors (Innovation) play an important moderating role in the model. The results also revealed that innovation statistically moderates the relationship between Internal Social Capital and Financial and Operational Performance respectively $(\beta=0.343, \mathrm{t}=5.667, \mathrm{p}<0.05 ; \beta=0.395, \mathrm{t}=7.417, \mathrm{p}<0.05)$, innovation also moderates the relationship between External Capital Internal Social Capital and Financial and Operational Performance respectively $(\beta=0.349, \mathrm{t}=4.929, \mathrm{p}<0.05 ; \beta=0.0 .277, \mathrm{t}=4.686, \mathrm{p}<0.05)$. The third hypothesis of the study is therefore confirmed and concludes that innovation mediates amid Social Capital practices and SMEs performance. It reveals innovation strengthening Social Capital practices and SMEs performance.

Table 3: Direct Relationships

\begin{tabular}{llll}
\hline Hypotheses & Path & T Statistics & P Values \\
& Coefficients & & 0.000 \\
\hline $\mathrm{H}_{1 \mathrm{a}}:$ Internal Capital -> Financial Performance & 0.287 & 4.609 & 0.000 \\
$\mathrm{H}_{1 \mathrm{~b}}:$ Internal Capital -> Operational Performance & 0.347 & 5.338 & 0.000 \\
$\mathrm{H}_{2 \mathrm{a}}:$ External Capital -> Financial Performance & 0.213 & 3.560 & 0.000 \\
$\mathrm{H}_{2 \mathrm{~b}}:$ External Capital -> Operational Performance & 0.360 & 5.847 & 0.000 \\
$\mathrm{H}_{3 \mathrm{a}}:$ Innovation (Internal Capital -> Financial Performance) & 0.343 & 5.667 & 0.000 \\
$\mathrm{H}_{3 \mathrm{~b}}:$ Innovation (Internal Capital -> Operational Performance) & 0.395 & 7.417 & 0.000 \\
& 0.349 & 4.929 & 0.000 \\
$\mathrm{H}_{3 \mathrm{c}}:$ Innovation (External Capital -> Financial Performance) & 0.277 & 4.686 & 0 \\
$\mathrm{H}_{3 \mathrm{~d}}$ Innovation (External Capital -> Operational Performance) & & & 0.000 \\
\hline
\end{tabular}

\subsection{Discussion of findings}

The study envisaged contributing to the development and validation of the RBV and Social Capital theories by evaluating SME's view on the role of Social Capital in generating innovative ideas to stimulate performance among firms. The outcome of the study revealed that all five [5] hypotheses were supported; the various relationships are discussed below. The result showed that the social capital initiatives of the SMEs yielded a significant direct effect on performances. The internal and external social capital initiatives of firms were positively associated with performance and also statistically significant. Thus, the c social capital initiatives exerted a significant effect on the performances of the SMEs. This finding is therefore in line with proponents of the social capital theory Hyuk \& Park, 2018) and many empirical kinds of literature on social capital that reports the positive significant effect of social capital on firm performance (Pratono, Saputra \& Pudjibudojo, 2016; Hyuk \& Park, 2018; Ozigi, 2018). It is inferred that information flow is critical resources managers can tap to the benefit of their firms. Thus, the free flow of information facilitates business activities and higher firm performance. Usually, at the initial stage of their business through an effective and easy mobilizing financial resources to a start-up business. The outcome of the study indicates that social capital and innovation generate superior performance among SMEs. This knowledge will improve the performance of SMEs and their ability to withstand the competition in the industry. The discovery of this study provides empirical support to the Resource-based view theory. Thus, practitioners in the SME business give priority to factors that could enhance innovation in their operations as well as implement strategies to derive social capital formation as they tend to foster superior performance and competitive advantages. The study of Agyapong et al. (2017) posited that the adoption of social capital for firms owned by families that intend to pursue innovation. From the final SEM estimated model, the innovation initiatives of the SMEs moderate the relationship between the social capital practices of the firms and 
performance. This conclusion is drawn from the fact that social capital was statistically significantly associated with innovation, and innovation was also significantly associated with performance. Thus, the indirect effects of the relationship were statistically significant. Firms are motivated to innovate under difficult marketing conditions that often emanate from dynamic changes and environmental uncertainties. Nonetheless, several studies emphasize that the effect of innovation firm performance is neither direct nor deterministic but require some internal capital stock in the form of social capital (Huang \& Rice, 2009). Many firms in the industry-specific environment are developing enormous interest in utilizing or tapping into social capital to maximize performance. Several studies in the extant literature concur to the positive relationship between social capital and firm performance (e.g., Stam, Arzlanian \& Elfring, 2013; Barroso-Castro, Villegas-Periñan \& Casillas-Bueno, 2015; Akintimehin et al., 2019; Hongyun, Adomako, Appiah-Twum \& Akolgo, 2019). These studies emphasize that resources in the form of internal and external capital are now been utilized by firms to gain a competitive advantage in a very uncertain and dynamic business environment. Besides, the existing innovation literature also emphasizes that innovation indirectly exerts some influence on firm performance (Farhang, Abkenari \& Fadaee, 2018).

\section{Conclusion}

The SMEs in Ghana are highly embracing the various forms of social capital. Internally, cross-departmental coordination has become critical in driving the products or services of SMEs in Ghana. The staff within and across departments of SMEs are well-informed by colleagues at all times. Workers of SMEs in Ghana are trustworthy and exhibit a high level of integrity. Workers of SMEs are also committed to firm goals and as such share in the ambitions and visions of the firms. These social capital initiatives of the firms are yielding a higher effect on the operational performances of SMEs. The effect of social capital on the performance of the SMEs was revealed to be through the innovation initiatives of the firms. The social capital initiatives of the SMEs positively and significantly enhanced the innovation practices of the firms. Both internal and external social capital initiatives of the SMEs were positively and significantly associated with the innovation practices of the firms. Likewise, the innovation initiatives of the SMEs positively stimulated the performances of the firms. Thus, the innovation initiatives of the SMEs in Ghana moderated the relationship between the social capital initiatives of the firms and performance. Thus, the effect of the practices of social capital by SMEs on firm performance is direct and indirect through their level of innovation practices.

\subsection{Contribution to Theory and Practice}

Theoretically, this study provides adequate support to social capital theory and resource-based view that a company's utilization of valuable, rare, inimitable and non-substitutable resources offers some level of competitive advantage for superior performance in an industry (Wernerfelt, 1984; Barney, 1991; Collis \& Montgomery, 1995). This is evident from the positive utilization of the social capital of SMEs to stimulate a higher level of performance directly and indirectly through innovation. This study also vehemently contributes ideally to knowledge, in the sense that, the extant literature on social capital and performance of SMEs has separately assessed innovation as a mediator but not simultaneously. Nonetheless, these concepts do not occur in practice separately but 
simultaneously. This study, therefore, contributed to knowledge building by simultaneously assessing the mediating role of innovation in the association between the social capital and performance of SMEs.

\subsection{Recommendations}

This section provides measures that can be employed at the policy and managerial level to stimulate a higher level of performance of firms through social capital and innovation initiatives.

Social capital can be positively utilized by SMEs to enhance performance indirectly through innovation. However, there are many SMEs in Ghana without research and development units to promote a higher level of innovative initiatives to stimulate higher performance. This study, therefore, recommends that SMEs with the desire to generate higher performance through sustainable competitive advantage start investing in research and development. With higher investment in $\mathrm{R} \& \mathrm{D}$, new products and new processes could be developed to offer the firms some level of competitive advantage that can be utilized to sustain higher performance.

Notwithstanding the postulated positive outcome of social capital on firm performance indirectly through innovation, knowledge and awareness of many CEOs and managers of SMEs are limited on the concept. Many CEOs and managers do not necessarily classify social capital as a critical resource that can be utilized to enhance firm performance through innovative initiatives. To curtail this issue, it is imperative for individuals' firms, the Business Advisory Centre (BAC) and National Board for Small Scale Industries (NBSSI) to organize periodic workshops and training programs on social capital practices and utilization as a rare asset for reaping higher performance. Future studies using longitudinal research design could be useful in such a similar study. Though the study had no issues of common method bias despite using a single respondent, future studies must consider multiple respondents from each firm. Again, this current sample size is comparable to the minimum required for this form of research, future research should attempt to reach a larger sample size to improve external validity. This will also support research efforts by fine-tuning the measures and specifically optimizing for variables like social capital and innovation.

\section{References}

Ab Hamid, M. R., Sami, W., \& Sidek, M. M. (2017, September). Discriminant validity assessment: Use of Fornell \& Larcker criterion versus HTMT criterion. In Journal of Physics: Conference Series (Vol. 890, No. 1, p. 012163). IOP Publishing.

Abor, J., \& Quartey, P. (2010). Issues in SME development in Ghana and South Africa. International research journal of finance and economics, 39(6), 215-228.

Agyapong, F. O., Agyapong, A., \& Poku, K. (2017). Nexus between social capital and performance of micro and small firms in an emerging economy: The mediating role of innovation. Cogent Business \& Management, 4(1), 1309784.

Akintimehin, O. O., Eniola, A. A., Alabi, O. J., Eluyela, D. F., Okere, W., \& Ozordi, E. (2019). Social capital and its effect on business performance in the Nigeria informal sector. Heliyon, 5(7), e02024.

Akintimehin, O. O., Eniola, A. A., Alabi, O. J., Eluyela, D. F., Okere, W., \& Ozordi, E. (2019). Social capital and its effect on business performance in the Nigeria informal sector. Heliyon, 5(7), e02024.

Akintimehin, O. O., Eniola, A. A., Olorunleke, G. K., Ojeka, J. D., \& Oyetunji, B. (2019). The impact of organizational culture on total quality management in SMEs in Nigeria. Heliyon, 5(8), e02293. 
Akram, J., \& Eaton, D. W. (2016). Refinement of arrival-time picks using a cross-correlation based workflow. Journal of Applied Geophysics, 135, 55-66.

Alegre, J., Lapiedra, R., \& Chiva, R. (2006). A measurement scale for product innovation performance. European Journal of Innovation Management.

Al-Tabbaa, O., \& Ankrah, S. (2016). Social capital to facilitate 'engineered' university-industry collaboration for technology transfer: A dynamic perspective. Technological Forecasting and Social Change, 104, 1-15.

Anderson, P. (2009). The new old world. Verso Books.

Armstrong, J. S., \& Overton, T. S. (1977). Estimating nonresponse bias in mail surveys. Journal of marketing research, 14(3), 396-402.

Aryeetey, E. (2001). Priority research issues relating to regulation and competition in Ghana (No. 1649-2016-135966).

Asgary, A., Ozdemir, A. I., \& Ozyurek, H. (2020). Small and Medium Enterprises and Global Risks: Evidence from Manufacturing SMEs in Turkey.

Awang, Z. (2012). Research methodology and data analysis second edition. UiTM Press.

Bagah, D. A., Angko, W., \& Tanyeh, J. P. (2016). Environmental Degradation and Small Scale Mining Nexus: Emerging Trends and Challenges in Northern Ghana.

Bagorogoza, J., \& de Waal, A. (2010). The role of knowledge management in creating and sustaining high performance organisations: The case of financial institutions in Uganda. World Journal of Entrepreneurship, Management and Sustainable Development.

Bakar, L. J. A., \& Ahmad, H. (2010). Assessing the relationship between firm resources and product innovation performance. Business Process Management Journal.

Barney, J. (1991). Firm resources and sustained competitive advantage. Journal of management, 17(1), 99-120.

Barroso-Castro, C., Villegas-Periñan, M. D. M., \& Casillas-Bueno, J. C. (2015). How boards' internal and external social capital interact to affect firm performance. Strategic Organization, 14(1), 6-31.

Bashir, M., Bari, M. W., \& Raza, S. H. (2018). Dimensions of Social Capital and Innovation Capabilities of Firms: The Performance of Information Technology as a Mediator. Global Social Sciences Review, 3(3), 175-192.

Batjargal, B. (2003). Social capital and entrepreneurial performance in Russia: A longitudinal study. Organization studies, 24(4), 535-556.

Bhagavatula, S., Elfring, T., Van Tilburg, A., \& Van De Bunt, G. G. (2010). How social and human capital influence opportunity recognition and resource mobilization in India's handloom industry. Journal of Business Venturing, 25(3), 245-260.

Boschma, R. (2005). Role of proximity in interaction and performance: Conceptual and empirical challenges.

Byrne, B. M. (2013). Structural equation modeling with Mplus: Basic concepts, applications, and programming. routledge.

Camps, S., \& Marques, P. (2014). Exploring how social capital facilitates innovation: The role of innovation enablers. Technological Forecasting and Social Change, 88, 325-348.

Castro, I., \& Roldán, J. L. (2013). A mediation model between dimensions of social capital. International Business Review, 22(6), 1034-1050.

Chang, L., Chen, B. B., \& Ji, L. Q. (2011). Attributions and attitudes of mothers and fathers in China. Parenting, 11(2-3), 102-115.

Chen, L., Zheng, W., Yang, B., \& Bai, S. (2016). Transformational leadership, social capital and organizational innovation. Leadership \& Organization Development Journal.

Chichoni, H. (2011). LEGAL TRENDS-I-9 Compliance Crackdowns-I-9 policies need to be shipshape as the government cracks down on noncompliant forms. HRMagazine, 56(2), 63.

Chin, W. W. (1998). Commentary: Issues and opinion on structural equation modeling.

Cho, H. O. (2018). Investigating the Effect of Value Characteristics of SNS Users on SNS Usage Motivation, Social Capital, and Usage Behavior. Journal of Digital Contents Society, 19(2), 351-362.

Chowdhury, S. R. (2011). Impact of global crisis on small and medium enterprises. Global Business Review, 12(3), 377-399.

Coleman, J. S. (1990). Commentary: Social institutions and social theory. American Sociological Review, 55(3), 333-339. 
Costanza, R., Fisher, B., Ali, S., Beer, C., Bond, L., Boumans, R., ... \& Snapp, R. (2007). Quality of life: An approach integrating opportunities, human needs, and subjective well-being. Ecological economics, 61(23), 267-276.

Crescenzi, R., Gagliardi, L., \& Percoco, M. (2013). The 'bright'side of social capital: How 'bridging'makes Italian provinces more innovative. In Geography, institutions and regional economic performance (pp. 143164). Springer, Berlin, Heidelberg.

Dai, W., \& Liu, Y. (2015). Local vs. non-local institutional embeddedness, corporate entrepreneurship, and firm performance in a transitional economy. Asian Journal of Technology Innovation, 23(2), 255-270.

Dakhli, M., \& De Clercq, D. (2004). Human capital, social capital, and innovation: a multi-country study. Entrepreneurship \& regional development, 16(2), 107-128.

Darroch, J. (2005). Knowledge management, innovation and firm performance. Journal of knowledge management.

De Long, D. W., \& Fahey, L. (2000). Diagnosing cultural barriers to knowledge management. Academy of Management Perspectives, 14(4), 113-127.

Duffy, M. K., Scott, K. L., Shaw, J. D., Tepper, B. J., \& Aquino, K. (2012). A social context model of envy and social undermining. Academy of management Journal, 55(3), 643-666.

Duran, P., Kammerlander, N., Van Essen, M., \& Zellweger, T. (2016). Doing more with less: Innovation input and output in family firms. Academy of management Joumal, 59(4), 1224-1264.

Erselcan, F. (2015). Relevance of education to real life and of real life to education-Experiential learning for international business. Procedia-social and behavioral sciences, 177, 401-405.

Fafchamps, M., \& Minten, B. (2002). 4 Social capital and the firm: evidence from. The role of social capital in development: An empirical assessment, 125.

Fafchamps, M., \& Minten, B. (2002). Returns to social network capital among traders. Oxford economic papers, 54(2), 173-206.

Falk, R. F., \& Miller, N. B. (1992). A primer for soft modeling. University of Akron Press.

Farhang, H. S., Abkenari, H. A., \& Fadaee, M. (2018). The Impact of Organizational Innovation on the Performance of Manufacturing Firms Through Innovation Capabilities in Process and Product. Iranian Journal of Optimization, 10(2), 75-80.

Farhang, H. S., Abkenari, H. A., \& Fadaee, M. (2018). The Impact of Organizational Innovation on the Performance of Manufacturing Firms Through Innovation Capabilities in Process and Product. Iranian Journal of Optimization, 10(2), 75-80.

Florin, J., Lubatkin, M., \& Schulze, W. (2003). A social capital model of high-growth ventures. Academy of Management Journal, 46(3), 374-384.

Fornell, C., \& Larcker, D. F. (1981). Structural equation models with unobservable variables and measurement error: Algebra and statistics.

Fountain, J. E. (1998). Social capital: Its relationship to innovation in science and technology. Science and Public Policy, 25(2), 103-115.

Garrigós-Simón, F. J., \& Marqués, D. P. (2004). Competitive strategies and firm performance. Management Research: Journal of the Iberoamerican Academy of Management.

Gold, A. H., Malhotra, A., \& Segars, A. H. (2001). Knowledge management: An organizational capabilities perspective. Journal of management information systems, 18(1), 185-214.

Grant, R. M. (1991). The resource-based theory of competitive advantage: implications for strategy formulation. California management review, 33(3), 114-135.

Grant, R. M. (1996). Prospering in dynamically-competitive environments: Organizational capability as knowledge integration. Organization science, 7(4), 375-387.

Gunday, G., Ulusoy, G., Kilic, K., \& Alpkan, L. (2011). Effects of innovation types on firm performance. International Journal of production economics, 133(2), 662-676.

Hair, J. F., Ringle, C. M., \& Sarstedt, M. (2013). Partial least squares structural equation modeling: Rigorous applications, better results and higher acceptance. Long range planning, 46(1-2), 1-12.

Hair, J. F., Risher, J. J., Sarstedt, M., \& Ringle, C. M. (2019). When to use and how to report the results of PLS-SEM. European business review. 
Hair, J. F., Sarstedt, M., Ringle, C. M., \& Mena, J. A. (2011). An assessment of the use of partial least squares structural equation modeling in marketing research. Journal of the academy of marketing science, 40(3), 414433.

Hair, J., Hollingsworth, C. L., Randolph, A. B., \& Chong, A. Y. L. (2010). An updated and expanded assessment of PLS-SEM in information systems research. Industrial Management \& Data Systems.

Hair Jr, J. F., Sarstedt, M., Hopkins, L., \& Kuppelwieser, V. G. (2014). Partial least squares structural equation modeling (PLS-SEM): An emerging tool in business research. European business review.

Harman, C., \& Brelade, S. (2000). Knowledge Management and the Role of HR. Financial Times/Prentice Hall.

Henseler, I., Falkai, P., \& Gruber, O. (2010). Disturbed functional connectivity within brain networks subserving domain-specific subcomponents of working memory in schizophrenia: relation to performance and clinical symptoms. Journal of Psychiatric Research, 44(6), 364-372.

Henseler, J., Hubona, G., \& Ray, P. A. (2016). Using PLS path modeling in new technology research: updated guidelines. Industrial management \& data systems.

Henseler, J., Ringle, C. M., \& Sarstedt, M. (2015). A new criterion for assessing discriminant validity in variance-based structural equation modeling. Journal of the academy of marketing science, 43(1), 115-135.

Herrmann, A., Tomczak, T., \& Befurt, R. (2006). Determinants of radical product innovations. European Journal of Innovation Management.

Hongyun, T., Kankam, W. A., Appiah-Twum, F., \& Akolgo, I. G. (2019). Effect of social capital on firm performance: The role of entrepreneurial orientation and dynamic capability. International Review of Management and Marketing, 9(4), 63.

Huang, F., \& Rice, J. (2009). The role of absorptive capacity in facilitating" Open innovation" outcomes: A study of Australian SMEs in the manufacturing sector. International Journal of Innovation Management, 13(02), 201-220.

Huang, F., \& Rice, J. (2009). The role of absorptive capacity in facilitating" Open innovation" outcomes: A study of Australian SMEs in the manufacturing sector. International Journal of Innovation Management, 13(02), 201-220.

Huang, G., Chen, D., Li, T., Wu, F., Van Der Maaten, L., \& Weinberger, K. Q. (2017). Multi-scale dense convolutional networks for efficient prediction. arXiv preprint arXiv:1703.09844, 2.

Ibanga, D. A. (2015). Solving the problem of poor quality of university graduates in Nigeria: A proposed holistic approach.

Igwe, P. A., Ogundana, A. N. A. O. M., Egere, O. M., \& Anigbo, J. A. (2018). Factors affecting the investment climate, SMEs productivity and entrepreneurship in Nigeria. European Journal of Sustainable Development, 7(1), 182-182.

Jo, D. H., \& Park, J. W. (2018). Exploring the role of social capital in implementing a collaborative SCM system. Journal of Theoretical and Applied Information Technology, 96(2), 445-454.

Jones, T., \& Taylor, S. F. (2012). Service loyalty: accounting for social capital. Journal of Services Marketing.

Kaasa, A., Kaldaru, H., \& Parts, E. (2007). Social capital and institutional quality as factors of innovation: evidence from Europe. University of Tartu Faculty of Economics and Business Administration Working Paper, (55-2007).

Karabulut, A. T. (2015). Effects of innovation types on performance of manufacturing firms in Turkey. Procedia-Social and Behavioral Sciences, 195, 1355-1364.

karim Suhag, A., Solangi, S. R., Larik, R. S. A., Lakho, M. K., \& Tagar, A. H. (2017). The relationship of innovation with organizational performance. International Journal of Research-Granthaalayah, 5(2), 292306.

Kline, R. B. (2011). Convergence of structural equation modeling and multilevel modeling.

Landry, R., Amara, N., \& Lamari, M. (2002). Does social capital determine innovation? To what extent?. Technological forecasting and social change, 69(7), 681-701.

Langley, R. G. B., Krueger, G. G., \& Griffiths, C. E. M. (2005). Psoriasis: epidemiology, clinical features, and quality of life. Annals of the rheumatic diseases, 64(suppl 2), ii18-ii23.

Liao, Y., \& Marsillac, E. (2015). External knowledge acquisition and innovation: the role of supply chain network-oriented flexibility and organisational awareness. International Journal of Production Research, 53(18), 5437-5455. 
Marques, F. O., Taborda, R. M., \& Antunes, J. V. (2005). 2D rotation of rigid inclusions in confined bulk simple shear flow: a numerical study. Journal of Structural Geology, 27(12), 2171-2180.

Mbuyisa, B., \& Leonard, A. (2017). The role of ICT use in SMEs towards poverty reduction: A systematic literature review. Journal of International Development, 29(2), 159-197.

Meseguer-Martinez, A., Ruiz-Ortega, M. J., \& Parra-Requena, G. (2018). The effect of structural social capital on innovation performance through absorptive capacity. The case of a science park. Revista ESPACIOS, 39(24).

Nahapiet, J., \& Ghoshal, S. (1998). Social capital, intellectual capital, and the organizational advantage. Academy of management review, 23(2), 242-266.

Nguyen, H. (2015). Social capital and firm performance: A study on manufacturing and services firms in Vietnam. Management Science Letters, 10(11), 2571-2582.

Nupus, H., Setiadi, R., \& Soesanto, H. (2016). The effect of social capital on the product innovativeness and marketing performance in Indonesian furniture small and medium-sized enterprises. International Review of Management and Marketing, 6(7), 355-360.

Ortiz, B., Donate, M. J., \& Guadamillas, F. (2017). Relationships between structural social capital, knowledge identification capability and external knowledge acquisition. European Journal of Management and Business Economics.

Packer, H., Schmidt, J., \& Bailey, M. (2020). Social networks and seafood sustainability governance: Exploring the relationship between social capital and the performance of fishery improvement projects. People and Nature, 2(3), 797-810.

Parker, A., Halgin, D. S., \& Borgatti, S. P. (2015). Dynamics of social capital: Effects of performance feedback on network change. Organization studies, 37(3), 375-397.

Pérez-Luño, A., Medina, C. C., Lavado, A. C., \& Rodríguez, G. C. (2011). How social capital and knowledge affect innovation. Journal of Business Research, 64(12), 1369-1376.

Pérez-Luño, A., Wiklund, J., \& Cabrera, R. V. (2011). The dual nature of innovative activity: How entrepreneurial orientation influences innovation generation and adoption. Journal of business Venturing, 26(5), 555-571.

Peteraf, M. A. (1993). The cornerstones of competitive advantage: a resource-based view. Strategic management journal, 14(3), 179-191.

Politis, J. D. (2003). The connection between trust and knowledge management: what are its implications for team performance. Journal of knowledge management.

Pratono, A. H. (2018). Does firm performance increase with risk-taking behavior under information technological turbulence? Empirical evidence from Indonesian SMEs. The Journal of Risk Finance.

Pratono, A. H., Saputra, R. S., \& Pudjibudojo, J. K. (2016). The social capital and firm performance: Evident from Indonesia small businesses. International Journal of Economics and Financial Issues, 6(S\&), 47-50.

Preacher, K. J., \& Hayes, A. F. (2008). Asymptotic and resampling strategies for assessing and comparing indirect effects in multiple mediator models. Behavior research methods, 40(3), 879-891.

Rosli, M. M., \& Sidek, S. (2013). The Impact of innovation on the performance of small and medium manufacturing enterprises:: Evidence from Malaysia. Journal of Innovation Management in Small \& Medium Enterprises, 2013, 1.

Sabitu, O., Kowo, S., \& Adenuga, O. (2019). The role of SMEs development on poverty alleviation in Nigeria. Insights into Regional Development, 1(3), 214-226.

Sanchez-Famoso, V., Maseda, A., \& Iturralde, T. (2014). The role of internal social capital in organisational innovation. An empirical study of family firms. European Management Journal, 32(6), 950-962.

Seibert, S. E., Kraimer, M. L., \& Liden, R. C. (2001). A social capital theory of career success. Academy of management journal, 44(2), 219-237.

Sforzi, J., \& Bianchi, M. (2020). Fostering social capital: the case of community-owned pubs. Social Enterprise Journal.

Smith, K. G., Collins, C. J., \& Clark, K. D. (2005). Existing knowledge, knowledge creation capability, and the rate of new product introduction in high-technology firms. Academy of management Journal, 48(2), 346357. 
Stam, W., \& Arzlanian, S. Elfring (2013). Social Capital of Entrepreneurs and Small Firm Performance: A Metaanalysis of Contextual and Methodological Moderators. Journal of Business Venturing.

Stan, C. V., Peng, M. W., \& Bruton, G. D. (2014). Slack and the performance of state-owned enterprises. Asia Pacific Journal of Management, 31(2), 473-495.

Stinchcombe, A. (1965). Organization-creating organizations. Society, 2(2), 34-35.

Tavitiyaman, P., Zhang, H. Q., \& Qu, H. (2012). The effect of competitive strategies and organizational structure on hotel performance. International Journal of Contemporary Hospitality Management.

Thompson, M. (2018). Social capital, innovation and economic growth. Journal of behavioral and experimental economics, 73, 46-52.

Tsai, W., \& Ghoshal, S. (1998). Social capital and value creation: The role of intrafirm networks. Academy of management Journal, 41(4), 464-476.

Tuan, N., Nhan, N., Giang, P., \& Ngoc, N. (2016). The effects of innovation on firm performance of supporting industries in Hanoi, Vietnam. Journal of Industrial Engineering and Management, 9(2), 413-431.

Vivero, R. L. (2002). The impact of process innovations on firm's productivity growth: the case of Spain. Applied Economics, 34(8), 1007-1016.

Voorhees, C. M., Brady, M. K., Calantone, R., \& Ramirez, E. (2016). Discriminant validity testing in marketing: an analysis, causes for concern, and proposed remedies. Journal of the academy of marketing science, 44(1), 119-134.

Wang, E. T., \& Tai, J. C. (2003). Factors affecting information systems planning effectiveness: organizational contexts and planning systems dimensions. Information \& Management, 40(4), 287-303.

Wernerfelt, B. (1984). A resource-based view of the firm. Strategic management journal, 5(2), 171-180.

Appendix 1: Validity and Reliability

\begin{tabular}{llllll}
\hline Constructs & Loadings & CA & CR & AVE & VIF \\
\hline Internal Social Capital & 0.946 & 0.850 & 0.899 & 0.690 & 2.154 \\
& 0.960 & & & & 2.234 \\
External Social Capital & 0.934 & & & & 2.178 \\
& 0.79 & 0.943 & 0.963 & 0.897 & 1.880 \\
& 0.857 & & & 1.616 \\
Financial Performance & 0.882 & & & & 2.242 \\
& 0.791 & & & 0.791 & 1.268 \\
& 0.904 & 0.868 & 0.919 & & 1.848 \\
Innovation & 0.891 & & & & 1.848 \\
& 0.873 & & & 0.826 & 2.107 \\
& 0.922 & 0.895 & 0.934 & & 2.240 \\
\hline Operational Performance & 0.888 & & & & 1.754 \\
& 0.917 & & & 0.932 & 2.237 \\
\hline
\end{tabular}

